\title{
Regulation of Insulin Resistance by Multiple MiRNAs via Targeting the GLUT4 Signalling Pathway
}

\author{
Tong Zhou ${ }^{a, b}$ Xianhong Meng ${ }^{a, c}$ Hui Che ${ }^{a}$ Nannan Shen ${ }^{b}$ Dan Xiao ${ }^{b}$ \\ Xiaotong Song ${ }^{b}$ Meihua Liang ${ }^{a}$ Xuelian Fu ${ }^{a}$ Jiaming Jub Yang Lid $^{d}$ Chaoqian X ${ }^{b}$ \\ Yong Zhang ${ }^{b, e}$ Lihong Wanga,f \\ aDepartment of Endocrinology, The Second affiliated Hospital of Harbin Medical University, Harbin, \\ ${ }^{b}$ Department of Pharmacology (the State-Province Key Laboratories of Biomedicine-Pharmaceutics \\ of China), Harbin Medical University, Harbin, 'Department of Gastroenterology, the Fourth Affiliated \\ Hospital of Harbin Medical University, Harbin, 'Center for Endemic Disease Control, Chinese Center \\ for Disease Control and Prevention, Key Lab of Etiology and Epidemiology, Education Bureau of \\ Heilongjiang Province \& Ministry of Health (23618504), Harbin Medical University, Harbin, eInstitute \\ of Metabolic Disease, Heilongjiang Academy of Medical Science, Harbin, Institute of Chronic Disease, \\ Heilongjiang Academy of Medical Science, Harbin, China
}

\section{Key Words}

Type 2 Diabetes Mellitus • Glucose transporter 4 - Mitogen-activated protein kinase 14 • Phosphatidylinositol 3-kinase regulatory subunit beta • MiR-106b • MiR-27a • MiR-30d • MTg-AMO • Insulin-resistant L6 cells
Abstract
Background/Aims: Type 2 Diabetes Mellitus (T2DM) is characterized by insulin resistance (IR), but the underlying molecular mechanisms are incompletely understood. MicroRNAs (miRNAs) have been demonstrated to participate in the signalling pathways relevant to glucose metabolism in IR. The purpose of this study was to test whether the multiple-target anti- miRNA antisense oligonucleotides (MTg-AMO) technology, an innovative miRNA knockdown strategy, can be used to interfere with multiple miRNAs that play critical roles in regulating IR. Methods: An MTg-AMO carrying the antisense sequences targeting miR-106b, miR-27a and miR-30d was constructed (MTg-AMO $\left.{ }_{106 \mathrm{~b} / 27 \mathrm{a} / 30 \mathrm{~d}}\right)$. Protein levels were determined by Western blot analysis, and transcript levels were detected by real-time RT-PCR (qRT-PCR). Insulin resistance was analysed with glucose consumption and glucose uptake assays. Results: We found that the protein level of glucose transporter 4 (GLUT4), Mitogen-activated protein kinase 14 (MAPK 14), Phosphatidylinositol 3-kinase regulatory subunit beta (PI3K regulatory subunit beta) and mRNA level of Slc2a4 (encode GLUT4), Mapk14 (encode MAPK 14) and Pik3r2 (encode PI3K regulatory subunit beta) were all significantly down-regulated in the skeletal muscle of diabetic
T. Zhou, X. Meng and H. Che contributed equally to this study.

\begin{tabular}{ll}
\hline Lihong Wang or Yong Zhang & Department of Endocrinology, the Second Affiliated Hospital of Harbin Medical \\
& University, 246 Xuefu Road, Nangang District, Harbin 150081, (China); Department of \\
& Pharmacology, Harbin Medical University, 157 Baojian Road, Nangang District, Harbin \\
& 150081, Heilongjiang Province, (China) \\
Tel. +86 4518667 1354, E-Mail nd6688@163.com / hmuzhangyong@hotmail.com
\end{tabular}




\section{Cellular Physiology Cell Physiol Biochem 2016;38:2063-2078 \\ \begin{tabular}{ll|l} 
and Biochemistry & Published online: May 11, 2016 & $\begin{array}{l}\text { @ 2016 The Author(s). Published by S. Karger AG, Basel } \\
\text { www.karger.com/cpb }\end{array}$ \\
\hline
\end{tabular} \\ Zhou et al.: Multiple miRNAs Regulate Insulin Resistance}

rats and in insulin-resistant L6 cells. Overexpression of miR-106b, miR-27a and miR-30d in L6 cells decreased glucose consumption and glucose uptake, and reduced the expression of GLUT4, MAPK 14 and PI3K regulatory subunit beta. Conversely, silencing of endogenous miR-106b, miR-27a and miR-30d in insulin-resistant L6 cells enhanced glucose consumption and glucose uptake, and increased the expression of GLUT4, MAPK 14 and PI3K regulatory subunit beta. MTg-AMO ${ }_{106 \mathrm{~b} / 27 \mathrm{a} / 30 \mathrm{~d}}$ up-regulated the protein levels of GLUT4, MAPK 14 and PI3K regulatory subunit beta, enhanced glucose consumption and glucose uptake. Conclusion: Our data suggested that miR-106b, miR-27a and miR-30d play crucial roles in the regulation of glucose metabolism by targeting the GLUT4 signalling pathway in L6 cells. Moreover, MTg$\mathrm{AMO}_{1066 / 27 a / 30 d}$ offers more potent effects than regular singular AMOs.

(C) 2016 The Author(s)

Published by S. Karger AG, Basel

\section{Introduction}

Type 2 Diabetes Mellitus (T2DM) is a metabolic disorder that is characterized by hyperglycaemia and it accounts for approximately $90 \%$ of all cases of diabetes [1-3]. Insulin resistance is a prominent feature central to the development of T2DM, which decreases the ability of insulin to interact with insulin-sensitive tissues (especially muscle, liver, and fat), impairs glucose utilization, and induces hepatic glucose output [4,5]. Although many genetic and physiological factors contribute to insulin resistance, the precise molecular mechanisms have not been elucidated. Glucose transporter 4, also known as GLUT4, is an insulinregulated glucose transporter found primarily in adipose, skeletal or cardiac tissues [6-9]. Insulin induces translocation of GLUT4 from intracellular vesicles to the plasma membrane, which permits the facilitated diffusion of circulating glucose down its concentration gradient into muscle cells leading to a rapid increase in the uptake of glucose. Accumulating evidence indicates that either expression deregulation or functional impairment of GLUT4 can cause insulin resistance. Because of its crucial role, GLUT4 has been considered to be a potential therapeutic target for T2DM.

MicroRNAs (miRNAs), a class of endogenous non-coding RNAs of approximately 22 nucleotides in length, play primary regulatory roles in animals and plants by binding to the $3^{\prime}$-untranslated regions (3'-UTR) of target mRNAs to induce degradation or repress translation [10-13]. Numerous studies have demonstrated that miRNAs are involved in many biological processes, such as cell development, differentiation, apoptosis and proliferation $[14,15]$. Notably, miRNAs have been documented to regulate insulin synthesis, secretion and sensitivity, differentiation of pancreas islet $\beta$-cell [16-20], glucose and lipid metabolism, and insulin resistance [21-23]. For example, overexpression of miR-29 leads to insulin resistance in 3T3-L1 adipocytes [24]; miR-320 augments insulin sensitivity during insulin resistance by regulating the insulin-IGF-1 signalling pathways [25]; miR-30d negatively regulates the expression of the insulin gene [17]; miR-133 regulates the expression of GLUT4 by targeting KLF15 in cardiomyocytes [26]; and miR-223 regulates GLUT4 expression and myocardial glucose metabolism [27]. Our pilot studies indicate that a number of miRNAs such as miR106b, miR-27a and miR-30d, in addition to miR-133 and miR-223, have the potential to target the GLUT4 gene and contribute to insulin resistance. This initial finding prompted us to hypothesize that insulin resistance is controlled by multiple miRNAs, through multiple signalling pathways or through a single gene as a common target of multiple miRNAs. More specifically, GLUT4 might be a common target of miR-133 and miR-223 as already documented by published studies, and of miR-106b, miR-27a and miR-30d, as well that remained yet to be examined. On the other hand, in considering utilizing miRNAs as therapeutic targets for GLUT4-associated insulin resistance, it remains unclear what is the superior strategy for the optimal reservation of GLUT4 function: manipulating a specific GLUT4-regulating miRNA or targeting GLUT4 regulator miRNAs. One of the indispensable approaches in miRNA research is knockdown of miRNAs by anti-miRNA oligonucleotides 


\section{Cellular Physiology Cell Physiol Biochem 2016;38:2063-2078 \\ \begin{tabular}{ll|l} 
and Biochemistry $10.1159 / 000445565$ & $\begin{array}{l}\text { P } 2016 \text { The Author(s). Published by S. Karger AG, Basel } \\
\text { www.karger.com/cpb }\end{array}$ \\
\hline
\end{tabular} \\ Zhou et al.: Multiple miRNAs Regulate Insulin Resistance}

(AMOs). Through irreversible binding to target miRNAs, AMOs allow for effective lossof-function of miRNAs and consequent gain-of-function of their target genes. To achieve concomitant knockdown of multiple miRNAs, co-application of multiple singular AMOs has been used. However this strategy, while effective in some cases, may be problematic in that control of equal transfection efficiency of several AMOs is difficult, if not impossible. To tackle this problem, our group has developed an innovative strategy: multiple-target AMO (MTg-AMO) technology [28]. MTg-AMO refers to a modified AMO carrying multiple antisense units that are engineered into a single oligonucleotides fragment to acquire the capacity of simultaneously silencing multiple-target miRNAs. Studies suggest that MTg-AMO is an improved approach for miRNA target gene discovery and for studying the functions of miRNAs. The aims of this study were two folds: first, to assess the possible roles of miR106b, miR-27a and miR-30d in regulating GLUT4 and their associated signalling pathways thereby their roles in insulin resistance; and second, to evaluate the efficacy of MTg-AMO in knocking down these miRNAs as compared with that of the regular AMOs. Our results support the view that insulin resistance is controlled by multiple miRNAs and simultaneous knockdown of multiple miRNAs yields a better efficacy in ameliorating insulin resistance caused by these miRNAs.

\section{Materials and Methods}

\section{Ethics statement}

This study was approved by the Ethic Committees of the Harbin Medical University. Experimental procedures and use of the rats were conducted in accordance with the Animal Care and Use Committee of the Harbin Medical University and conformed to the Guide for the Care and Use of Laboratory Animals published by the US National Institutes of Health (NIH Publication No. 85-23, revised 1996).

\section{Animals and establishment of diabetic model}

Male Wistar rats (180 - $220 \mathrm{~g}$ ) were obtained from the Animal Center of the 2nd Affiliated Hospital of Harbin Medical University, China. Animals were maintained at $24^{\circ} \mathrm{C}$ for one week and subjected to a $12 \mathrm{~h}: 12 \mathrm{~h}$ light-dark cycle with a constant humidity of $55 \pm 5 \%$. The rats were divided randomly into two groups: the control group and the Type 2 Diabetes Mellitus (T2DM) group. According to previous studies [29-31], the rats were intragastrically administered with a fat emulsion $(10 \mathrm{ml} / \mathrm{d})$ prepared with $20 \mathrm{~g}$ lard, $5 \mathrm{~g}$ cholesterol, $1 \mathrm{~g}$ thyreostat, $5 \mathrm{~g}$ sucrose, $1 \mathrm{~g}$ sodium glutamate, $5 \mathrm{~g}$ saccharum, $20 \mathrm{ml}$ tween-80, and $30 \mathrm{ml}$ propylene glycol, with a final volume of $100 \mathrm{ml}$ distilled water for $15 \mathrm{~d}$. Then, the animals were subjected to intraperitoneal injection of $30 \mathrm{mg} / \mathrm{kg} / \mathrm{d}$ streptozocin (STZ) in a $0.1 \mathrm{M}$ citrate buffer solution (pH4.2) for $3 \mathrm{~d}$. Animals were fasted for $12 \mathrm{~h}$ before sampling. Blood samples were collected and fasting blood glucose (FBG) level was detected at $72 \mathrm{~h}$ after the last injection of STZ to ensure that T2DM had been successfully established (glycaemia $>16.7 \mathrm{mmol} / \mathrm{L}$ ).

\section{Cell culture}

L6 skeletal muscle cells were obtained from the Shanghai Institutes for Biological Sciences (SIBS, China). The cells were cultured in $25 \mathrm{mmol} / \mathrm{L}$ glucose Dulbecco's Modified Eagle Medium (DMEM, Hyclone, Logan, UT, USA), supplemented with $10 \%$ fetal bovine serum (FBS) and 1\% penicillin/streptomycin (100 $\mu \mathrm{g} / \mathrm{ml}$ ) at $37^{\circ} \mathrm{C}, 5 \% \mathrm{CO}_{2}$. To develop a cellular model of insulin resistance (IR), L6 cells were treated with insulin $(1 \mu \mathrm{mol} / \mathrm{L})$ for $24 \mathrm{~h}$, and glucose consumption and uptake were measured to verify the status of IR.

\section{Cell transfection}

The miR-106b, miR-30d and miR-27a mimics, AMO-106b, AMO-27a, AMO-30d, and a negative control (NC) were synthesized by Guangzhou Ribo Bio Co., Ltd., China. The multiple-target AMO (MTg-AMO) was synthesized by EXIQON, USA. The MTg-AMO tested in this study was designed to integrate the AMOs against miR-106b, miR-27a and miR-30d into one AMO (MTg-AMO $\left.{ }_{106 \mathrm{~b} / 27 \mathrm{a} / 30 \mathrm{~d}}\right)$. The sequences of the anti-miRNA antisense inhibitors (AMOs), the multiple-target AMO (MTg-AMO), the mutant sequences of the AMOs and $\mathrm{MTg}^{-\mathrm{AMO}_{106 \mathrm{~b} / 27 \mathrm{a} / 30 \mathrm{~d}}}$ are listed as following: AMO-106b (5'-ATC TGC ACT GTC AGC ACT TTA-3'), Mutant AMO- 


\section{Cellular Physiology Cell Physiol Biochem 2016;38:2063-2078 \begin{tabular}{ll|l} 
and Biochemistry $10.1159 / 000445565$ & $\begin{array}{l}\text { P } 2016 \text { The Author(s). Published by S. Karger AG, Basel } \\
\text { www.karger.com/cpb }\end{array}$ \\
\hline
\end{tabular}}

Zhou et al.: Multiple miRNAs Regulate Insulin Resistance

106b (5'-ATC TGC ACT GTC ATA CTG GGC-3'); AMO-27a (5'-GCG GAA CTT AGC CAC TGT GAA-3'), Mutant AMO-27a (5'-GCG GAA CTT AGC CCT GTG TCC-3'); AMO-30d (5'-CTT CCA GTC GGG GAT GTT TACA-3'), Mutant AMO-30d (5'-CTT CCA GTC GGG GAG TGG GCAC-3'); MTg-AMO $_{106 \mathrm{~b} / 2 \mathrm{a} / 30 \mathrm{~d}}\left(5^{\prime}\right.$-ATC TGC ACT GTC AGC ACT TTA CTT AAA TGG CGG AAC TTA GCC ACT GTG AAC TTA AAT GCT TCC AGT CGG GGA TGT TTACA-3'), Mutant MTg-AMO 106b/27a/30d $\left(5^{\prime}\right.$-ATC TGC ACT GTC Ata CTG GGC CTT AAA TGG CGG AAC TTA GCC CTG TGT CCC TTA AAT GCT TCC AGT CGG GGA GTG GGCAC-3'). The constructs were added to L6 cells after they had been starved for $24 \mathrm{~h}$ in serum-free medium using the X-treme GENE siRNA transfection reagent (catalog\#: 04476093001; Roche, USA), according to the manufacturer's instructions. Protein and RNA samples were extracted for analysis $24 \mathrm{~h}$ after transfection.

\section{RNA isolation and quantitative real-time RT-PCR ( $q R T-P C R)$}

Total RNA samples were extracted from rat skeletal muscle tissue and L6 cells with TRIzol reagent (Invitrogen, Carlsbad, CA, USA). The cDNA was obtained by the Reverse Transcription Kit (Applied Biosystems, Carlsbad, CA, USA) according to the manufacturer's instructions. The SYBR Green PCR Master Mix Kit (Applied Biosystems, Carlsbad, CA, USA) was used in our study for the relative quantification of RNAs. Real-time PCR was performed with the 7500 Fast Real-Time PCR System (Applied Biosystems) to determine the relative levels of miR-106b, miR-27a, miR-30d, Slc2a4, Mapk14 and Pik3r2. The sequences of the primers used in this study are shown as following: Slc2a4 (Forward: 5 '-CCU CCU UUC CUC GCA GCA CUUUA-3', Reward: 5' - UAG ACG UGA CAG UCG UGA AAU-3'); Mapk14 (Forward: 5'-UGU CCA UCC CAC UUC ACU GUGAG-3'; Reward: 5' - CGC CUU GAA UCG GUG ACA CUU-3'); Pik3r2 (Forward: 5'-CCG CUG CGU CUG CCA UGU UUACA-3', Reward: 5' - GAA GGU CAG CCC CUA CAA AUGU-3'); GAPDH (Forward: 5'-AAG AAG GTG GTG AAG CAGGC-3', Reward: $5^{\prime}$ - TCC ACC ACC CAG TTG CTGTA-3'). QPCR was performed with 40 thermo cycles with GAPDH and U6 used as internal controls.

\section{Protein extraction and Western blot analysis}

The protein samples were extracted from L6 cells and rat skeletal muscle tissue. Total protein was quantified using the bicinchoninic acid (BCA) protein assay (Beyotime, China). Protein samples were fractionated by SDS-PAGE (12\% polyacrylamide gels) and transferred to nitrocellulose (NC) membranes. The membranes were blocked with Western blocking buffer for $2 \mathrm{~h}$ and then incubated at $4^{\circ} \mathrm{C}$ overnight. The following primary antibodies were used: GLUT4 (Abcam, USA), MAPK 14 (Cell Signaling Technology, Danvers, MA, USA), PI3K regulatory subunit beta (Cell Signaling Technology, Danvers, MA, USA) and GAPDH (Santa Cruz Biotechnology, Santa Cruz, CA). Images were detected using the Odyssey infrared imaging system (LI-COR, Lincoln, NB, USA). Western blot bands were quantified using Odyssey software by measuring the band intensity (Area×OD) for each group and the values were all normalized to GAPDH as an internal control.

\section{Immunofluorescence staining}

Cells were cultured in DMEM supplied with 10\% serum and stimulated by insulin $(1 \mu \mathrm{M})$, followed by incubation with lipofectamine 2000 containing miR-106b mimic, AMO-106b, miR-30d mimic, AMO-30d, miR-27a mimic, AMO-27a, MTg-AMO ${ }_{106 \mathrm{~b} / 27 \mathrm{a} / 30 \mathrm{~d}}$ MTg-NC or AMO-mix for $24 \mathrm{~h}$. The cells were fixed with $4 \%$ paraformaldehyde for $30 \mathrm{~min}$ at room temperature, permeabilized with $0.1 \%$ Triton $\mathrm{X}-100$ for $1 \mathrm{~h}$, and blocked with goat serum for $2 \mathrm{~h}$. GLUT4, MAPK 14 and PI3K regulatory subunit beta were incubated with their respective primary antibodies for $24 \mathrm{~h}$ and then with the conjugated secondary antibody for $1 \mathrm{~h}$. The nuclei were visualized with DAPI (4', 6-diamidino-2-phenylindole) at room temperature for $30 \mathrm{~min}$, and images (×20 magnification) were captured by a confocal fluorescent microscope.

\section{Glucose consumption assay}

Cells were grown on 6-well plates. After treatment, the culture medium was collected for measuring glucose concentration using the glucose oxidase method (F006, Nanjing Jiancheng Biological Engineering Research Institute, China).

Glucose uptake assay

L6 cells were serum starved and glucose uptake was measured with Glucose Uptake Cell-Based Assay Kit (No.600470, Cayman Chemical Company) according to the assay protocols. In brief, cells were treated 


\section{Cellular Physiology Cell Physiol Biochem 2016;38:2063-2078 \begin{tabular}{ll|l} 
and Biochemistry & Dublished online: May 11, 2016 & $\begin{array}{l}\text { @ 2016 The Author(s). Published by S. Karger AG, Basel } \\
\text { www.karger.com/cpb }\end{array}$ \\
\hline
\end{tabular} \\ Zhou et al.: Multiple miRNAs Regulate Insulin Resistance}

with insulin (100 nmol/L) for $30 \mathrm{~min}$, and then incubated for $10 \mathrm{~min}$ in glucose free medium containing 2-deoxyglucose. The amount of 2-NBDG taken up by cells was measured at the wavelengths designed to detect fluorescein.

\section{Luciferase assays}

The assays were carried out in a 48-well plate scale as previously described [32]. The $3^{\prime}$-UTRs of genes containing the conserved miRNA-binding sites and the mutated $3^{\prime}$-UTR were synthesized by Sangon Biotech Co., Ltd. (Shanghai, China) and amplified by PCR. The $3^{\prime}$-UTR luciferase vector was co-transfected with miRNA mimics or AMOs into human embryonic kidney 293 (HEK293) cells using Lipofectamine 2000 (Invitrogen), with Renilla luciferase reporters used as an internal control. Luciferase activity assay was performed $48 \mathrm{~h}$ following transfection using the Dual-Luciferase Reporter Assay System (Promega Biotech Co., Ltd.) according to the manufacturer's protocol.

\section{Data analysis}

Data are expressed as mean \pm S.E.M. Statistical comparisons were performed by t-test between two groups and one-way ANOVA for multiple comparisons. $\mathrm{P}<0.05$ was considered statistically significant. Data were analysed using the GraphPad Prism 5.0.

\section{Results}

Reciprocal changes of expression between IR-related proteins and miRNAs in IR cells

To explore the role of the GLUT4 signalling pathway in our rat model of T2DM and in insulin-resistant (IR) L6 cells, we first evaluated the changes of GLUT4, MAPK 14, and PI3K regulatory subunit beta expression at the protein level. As shown in Fig. 1A \& B, GLUT4, MAPK 14, and PI3K regulatory subunit beta were all significantly down-regulated in the diabetic group compared to the control group. We then measured the changes in miRNAs known to be associated with the skeletal muscle tissue of diabetic rats, including miR-17, miR-20, miR-24, miR-27a, miR-30d, miR-93, miR-106b and miR-520 [33-35]. Compared with the control group, miR-106b, miR-27a and miR-30d were significantly elevated in the diabetic group (data not shown). Using TargetScan miRNA database for target gene prediction, we found that the 3'-UTRs of Slc2a4 (encoding GLUT4), Mapk14 (encoding MAPK 14), and Pik3r2 (encoding PI3K regulatory subunit beta) genes carry the binding sites for miR-106b, miR-27a, and miR-30d, respectively.

\section{MiR-106b regulates GLUT4 expression and glucose metabolism}

As the first step towards understanding the possible role of miR-106b in insulin resistance, we established the relationship between miR-106b and GLUT4 using both gain- and loss-of-function approaches. As shown in Fig. 2A \& B, miR-106b suppressed the luciferase activity of the vector carrying the 3'-UTR of Slc2a4, whereas mutation of the binding sites attenuated the action of miR-106b. Consistently, overexpression of miR-106b in L6 cells significantly down-regulated the protein level of GLUT4 (Fig. 2C \& D). Conversely, knockdown of miR-106b by AMO-106b increased GLUT4 protein levels in insulin-resistant cells (Fig. 2E). Similar results were observed in our immunofluorescence experiments (Fig. $2 F \& G$ ). Strikingly, overexpression of miR-106b decreased the glucose consumption and uptake levels in L6 cells (Fig. 2H), and knockdown of miR-106b by AMO-106b increased them in IR L6 cells (Fig. 2I). Comparisons between the IR L6 cells (IR) and non-treated L6 cells (Control) showed that the glucose consumption and glucose uptake were significantly decreased in the former (Fig. 2I), indicating the development of IR after insulin treatment in L6 cells.

MiR-27a regulates MAPK 14 expression and glucose metabolism

We next investigated the link between miR-27a and MAPK 14 that carries two binding sites for miR-27a at its 3'-UTR (Fig. 3A). Our luciferase reporter gene assay clearly 


\section{Cellular Physiology Cell Physiol Biochem 2016;38:2063-2078 \begin{tabular}{ll|l} 
and Biochemistry & Dublished online: May 11, 2016 & $\begin{array}{l}\text { @ 2016 The Author(s). Published by S. Karger AG, Basel } \\
\text { www.karger.com/cpb }\end{array}$ \\
\hline
\end{tabular}
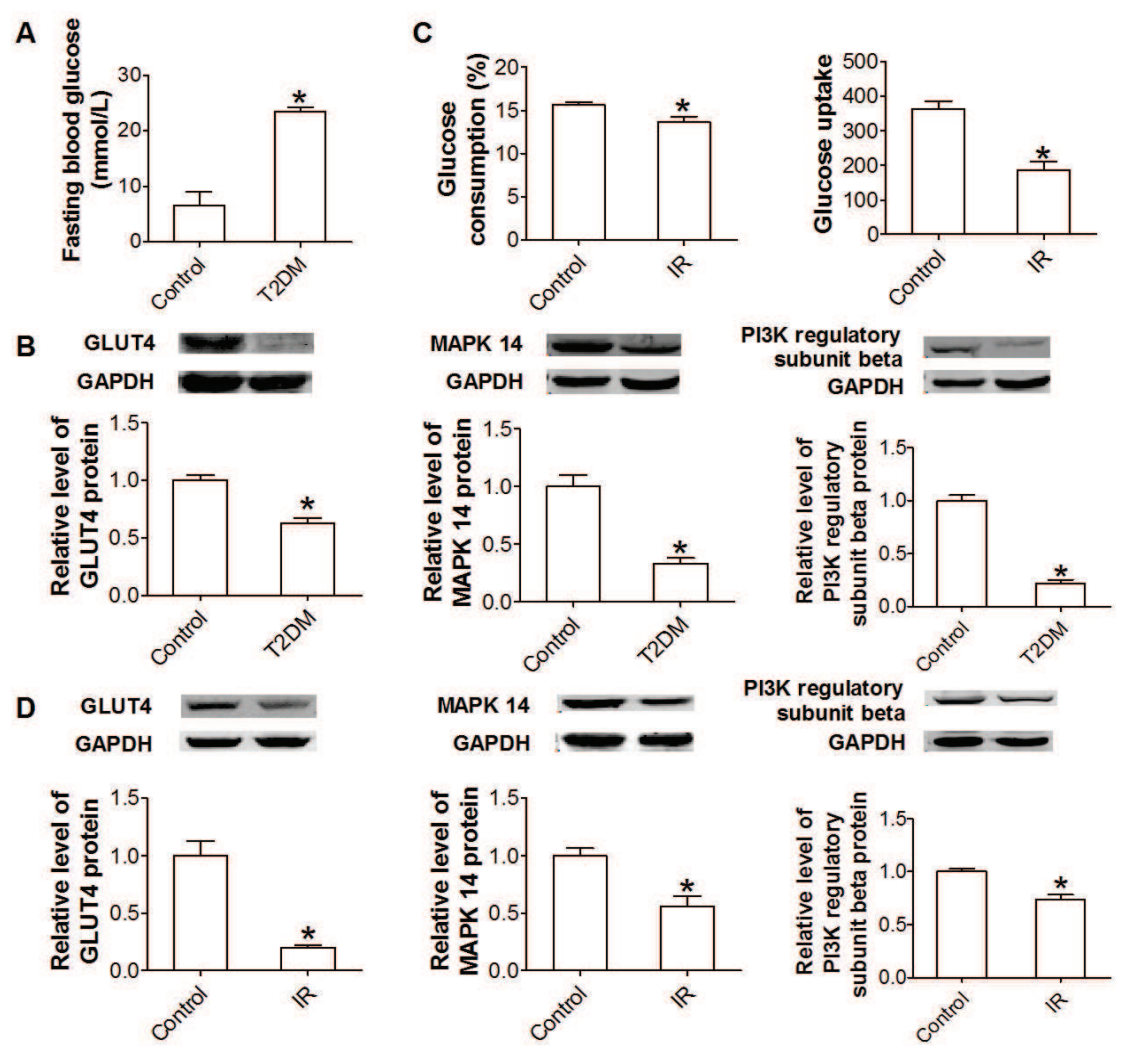

Fig. 1. Decreases in the GLUT4 signalling and impairment of glucose metabolism in insulin resistance. (A) Decrease in fasting blood glucose in a rat model of type 2 diabetes mellitus (T2DM). ${ }^{*} \mathrm{p}<0.05$ vs. Control; $\mathrm{n}=3-6$ in each group. (B) Decreases in GLUT4, MAPK 14 and PI3K regulatory subunit beta protein levels in a rat model of T2DM. Protein level was determined by Western blot analysis. Upper panels: representative Western blot bands; lower panels: averaged values of band density normalized to the internal control GAPDH and then to the control group to obtain the relative quantification. ${ }^{*} \mathrm{p}<0.01$ vs. Control; $\mathrm{n}=3-4$ rats in each group. (C) Decrease in glucose consumption and glucose uptake levels in insulin-resistant L6 cells (IR). Left panel: representative glucose consumption level; Right panel: representative glucose uptake level. $* \mathrm{p}<0.05$ vs. Control; $\mathrm{n}=3$ in each group. (D) Decreases in GLUT4, MAPK 14 and PI3K regulatory subunit beta protein levels in insulin-resistant L6 cells (IR). ${ }^{*} \mathrm{p}<0.05$ vs. Control; $\mathrm{n}=3$ in each group.

demonstrated that miR-27a suppressed the luciferase activity of the vector carrying the Mapk14 3'-UTR, whereas mutation of the binding sites relieved the repressive action of miR27a (Fig. 3B). Furthermore, the protein level of MAPK 14 was significantly reduced upon overexpression of miR-27a in IR L6 cells (Fig. 3C \& D); conversely, it was remarkably upregulated by AMO-27a to knockdown endogenous miR-27a (Fig. 3E). These results were reproduced by our immunofluorescence analysis (Fig. 3F \& G). Similar to miR-106b, miR-27a overexpression mitigated the glucose consumption and uptake in L6 cells, but its knockdown facilitated these processes in IR L6 cells (Fig. 3H \& I).

MiR-30d regulates PI3K regulatory subunit beta expression and glucose metabolism

We further determined the link between miR-30d and PI3K regulatory subunit beta using the same approach as described for miR-106b and miR-27a. As shown in Fig. 4A, Pik3r2 contains two conserved binding sites for miR-30d in its $3^{\prime}$-UTR. Transfection of miR-30d suppressed the luciferase activity generated by the vector carrying the $3^{\prime}$-UTR of Pik3r2, and 


\section{Cellular Physiology Cell Physiol Biochem 2016;38:2063-2078

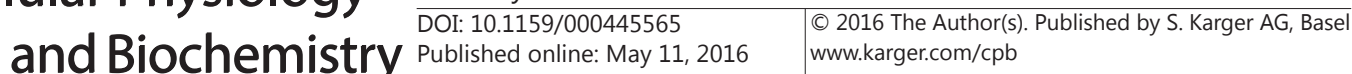

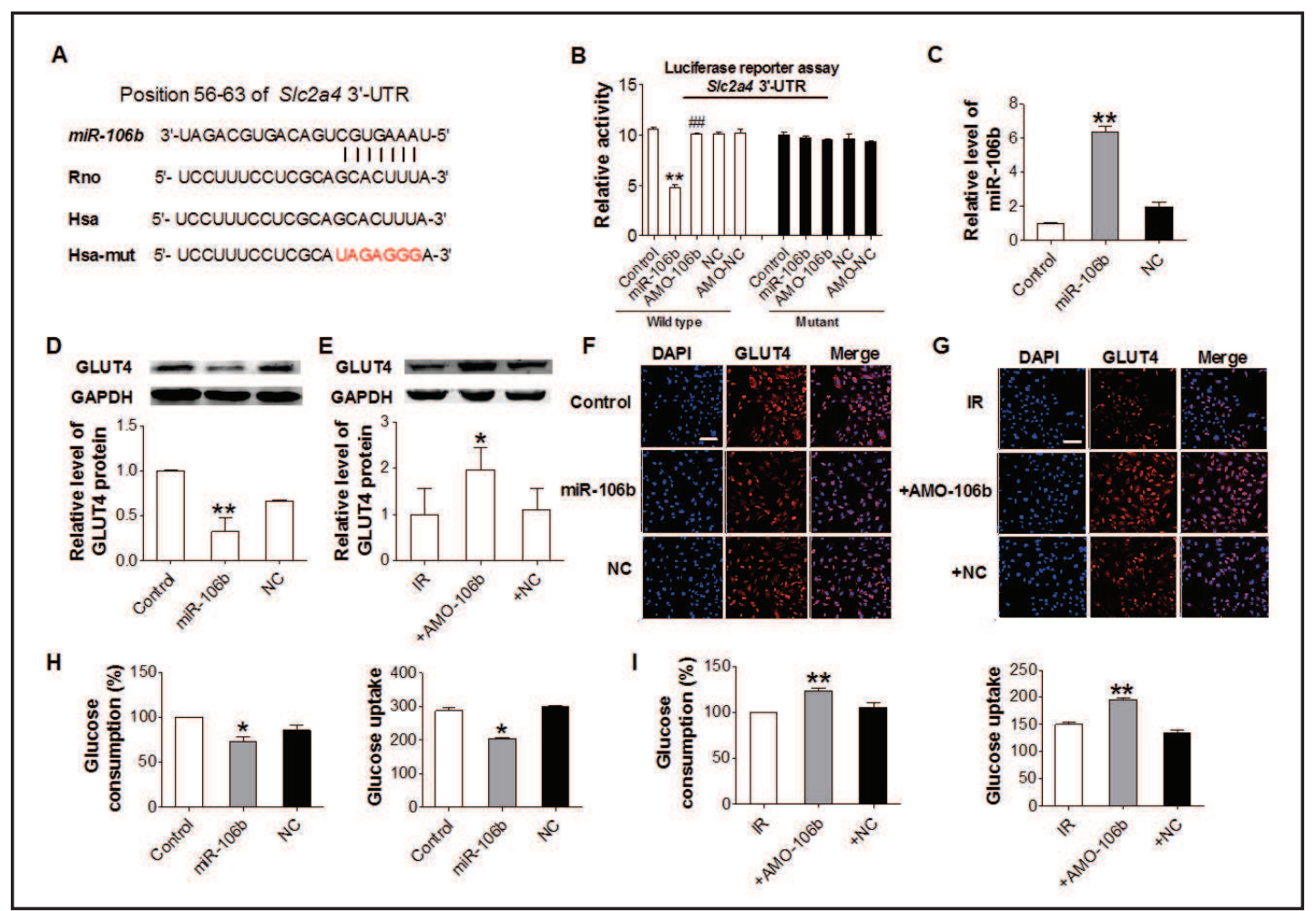

Fig. 2. MiR-106b targets GLUT4 to regulate glucose metabolism in skeletal muscles. (A) Sequence alignment showing the nucleotide complementarity between miR-106b and the $3^{\prime}$-UTR of the rat Slc2a4. The location of the nucleotide replacement mutation made to the seed site in $3^{\prime}$-UTR of Slc2a4 is indicated in red. (B) Luciferase reporter gene assay showing the direct functional interactions between miR-106b and the 3'-UTR of Slc2a4, as revealed by the significantly reduced luciferase activities by miR-106b mimics. Note that AMO106b, the antisense inhibitor of miR-106b, abolished the repressive effects and the mutated construct failed to affect luciferase activities. AMO-NC stands for negative control for AMO-106b. ${ }^{* *} \mathrm{p}<0.01$ compared with control; $\#$ p $<0.01$ compared with miR-106b; $n=3$. (C) Verification of transfection efficiency of miR-106b mimic in L6 cells, determined by real-time RT-PCR (qPCR) (normalized to U6 as an internal control). ${ }^{* *} \mathrm{p}<$ 0.01 versus control; $n=3$. (D) Downregulation of GLUT4 protein expression levels by miR-106b mimic in L6 cells. ${ }^{* *} \mathrm{p}<0.01$ vs. control; $\mathrm{n}=3$. (E) Upregulation of GLUT4 protein levels by AMO-106b to knockdown endogenous miR-106b in insulin-resistant L6 cells (IR). ${ }^{*} \mathrm{p}<0.05$ vs. IR; $n=3$. (F) Immunofluorescence staining showing the repressive effects of miR-106b on GLUT4 protein expression (red) in L6 cells. Cell nuclei were visualized by DAPI (blue). Scale bar $=100 \mu \mathrm{m}$. (G) Immunofluorescence staining showing the repressive effects of miR-106b on GLUT4 protein expression (red) in insulin-resistant L6 cells. Cell nuclei were visualized by DAPI (blue). Scale bar $=100 \mu \mathrm{m}$. (H) Inhibition of glucose consumption (left panel) and glucose uptake (right panel) by miR-106b mimics in L6 cells. The level of basal glucose uptake was set to $100 \%$. $\mathrm{p}<0.05$ compared with control; $\mathrm{n}=4$. (I) Enhancement of glucose consumption (left panel) and glucose uptake (right panel) by AM0-106b to knockdown miR-106b in insulin-resistant L6 cells (IR). ${ }^{* *} \mathrm{p}<$ 0.01 compared with control; $\mathrm{n}=4$.

this action was abrogated by the vector carrying the mutant binding sites (Fig. 4B). As depicted in Fig. 4C \& D, transfection of miR-30d into L6 cells remarkably reduced the protein level of PI3K regulatory subunit beta. In contrast, PI3K regulatory subunit beta was significantly upregulated in IR L6 cells transfected with AMO-30d (Fig. 4E). Immunostaining revealed that miR-30d overexpression markedly diminished PI3K regulatory subunit beta density and this effect was rescued by AMO-30d (Fig. $4 \mathrm{~F} \mathrm{\&} \mathrm{G).} \mathrm{In} \mathrm{addition,} \mathrm{the} \mathrm{glucose} \mathrm{consumption} \mathrm{level} \mathrm{and}$ glucose uptake were inhibited by miR-30d overexpression but improved by AMO-30d in IR L6 cells (Fig. 4H \& I). 


\section{Cellular Physiology Cell Physiol Biochem 2016;38:2063-2078 \begin{tabular}{cc|c} 
DOI: 10.1159/000445565 & $\begin{array}{l}\text { () 2016 The Author(s). Published by S. Karger AG, Basel } \\
\text { www.karger.com/cpb }\end{array}$
\end{tabular}

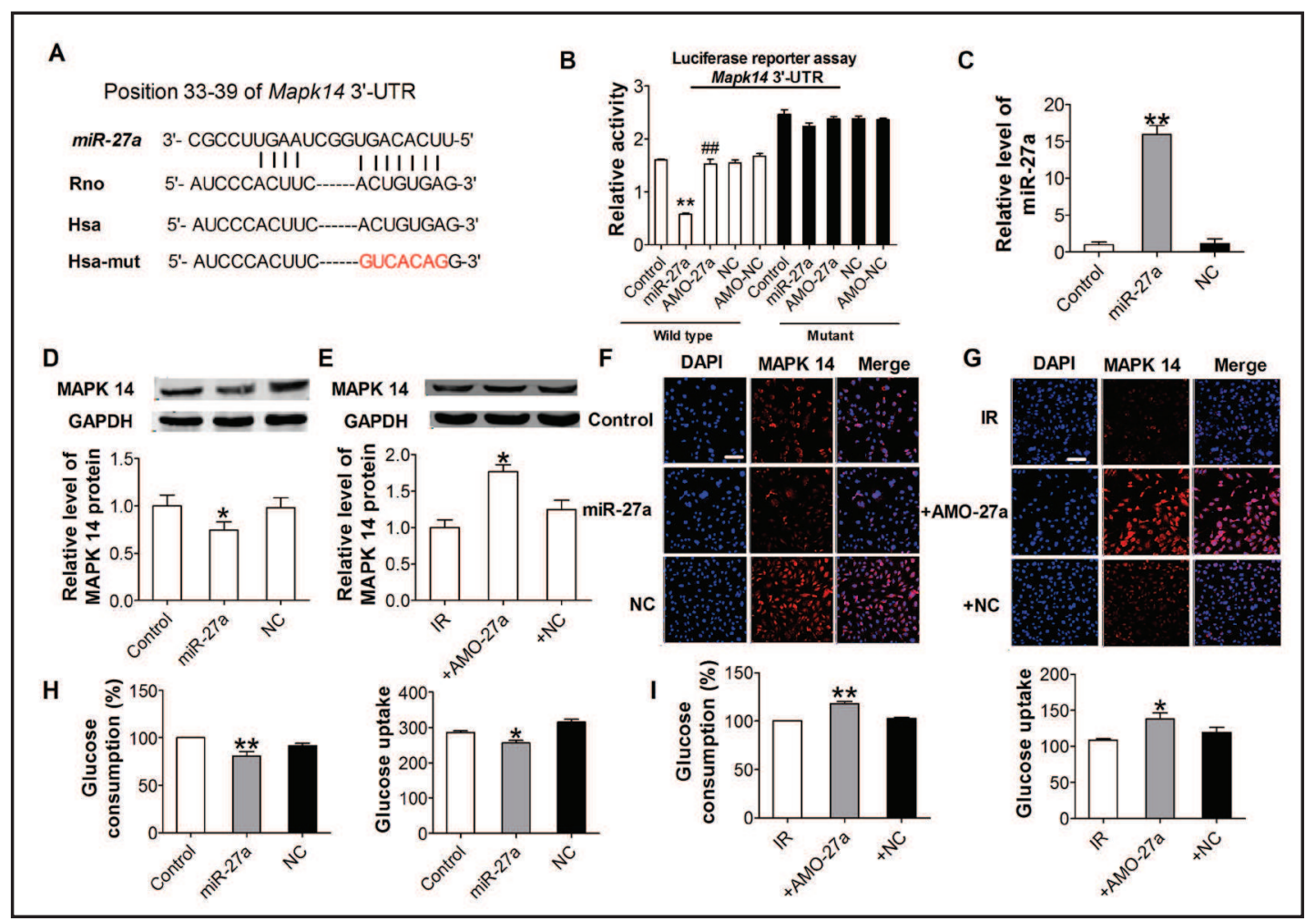

Fig. 3. MiR-27a targets MAPK 14 to regulate glucose metabolism in L6 cells. (A) Sequence alignment showing the nucleotide complementarity between miR-106b and the 3'-UTR of the rat Mapk14 gene that encodes MAPK 14. The location of the nucleotide replacement mutation made to the seed site in $3^{\prime}$-UTR of Mapk14 is indicated in red. (B) Luciferase reporter gene assay showing the direct functional interactions between miR-27a and the 3'-UTR of Mapk14, as revealed by the significantly reduced luciferase activities by miR27a mimic. Note that AMO-27a, the antisense inhibitor of miR-27a, abolished the repressive effects and the mutated construct failed to affect luciferase activities. AMO-NC stands for negative control for AMO-27a. ** $\mathrm{p}<0.01$ compared with control; \# $\mathrm{p}<0.01$ compared with miR-27a; $\mathrm{n}=3$. (C) Verification of transfection efficiency of miR-27a mimic in L6 cells, determined by real-time RT-PCR (qPCR) (normalized to U6 as an internal control). ${ }^{* *} \mathrm{p}<0.01$ versus control; $\mathrm{n}=3$. (D) Down-regulation of MAPK 14 protein expression levels by miR-27a mimic in L6 cells. * $\mathrm{p}<0.01$ vs. control; $\mathrm{n}=3$. (E) Upregulation of MAPK 14 protein levels by AM0-27a to knockdown endogenous miR-27a in insulin-resistant L6 cells (IR). * p < 0.05 vs. IR; $n=3$. (F) Immunofluorescence staining showing the repressive effects of miR-27a on MAPK 14 protein expression (red) in L6 cells. Cell nuclei were visualized by DAPI (blue). Scale bar $=100 \mu \mathrm{m}$. (G) Immunofluorescence staining showing the repressive effects of miR-27a on MAPK 14 protein expression (red) in insulin-resistant L6 cells. Cell nuclei were visualized by DAPI (blue). Scale bar $=100 \mu \mathrm{m}$. (H) Inhibition of glucose consumption (left panel) and glucose uptake (right panel) by miR-27a mimic in L6 cells. The level of basal glucose uptake was set to $100 \%{ }^{*} \mathrm{p}<0.05,{ }^{* *} \mathrm{p}<0.01$ compared with control; $\mathrm{n}=3-6$. (I) Enhancement of glucose consumption (left panel) and glucose uptake (right panel) by AMO-27a to knockdown miR-27a in insulin-resistant L6 cells (IR). ${ }^{*} \mathrm{p}<0.05,{ }^{* *} \mathrm{p}<0.01$ compared with control; $\mathrm{n}=3-4$.

MTg-AMO ${ }_{106 b / 27 a / 30 d}$ up-regulates GLUT4, MAPK 14 and PI3K regulatory subunit beta expression in L6 cells

The results presented above clearly indicate that multiple miRNAs (miR-106b, miR-27a and miR-30d) are involved in the regulation of the GLUT4/MAPK 14/PI3K regulatory subunit beta signalling pathway. Together with our data showing the substantial upregulation of all these three miRNAs in T2DM and IR cells, we contemplated that it might be highly desirable to simultaneously knockdown these miRNAs in order to achieve a better outcome in correcting IR. To test this notion, we first assessed the efficacy of $M T g-A M O_{106 \mathrm{~b} / 27 \mathrm{a} / 30 \mathrm{~d}}$ to knockdown 


\section{Cellular Physiology Cell Physiol Biochem 2016;38:2063-2078 \begin{tabular}{ll|l} 
DOI: 10.1159/000445565 & $\begin{array}{l}\text { () 2016 The Author(s). Published by S. Karger AG, Basel } \\
\text { www.karger.com/cpb }\end{array}$
\end{tabular}}

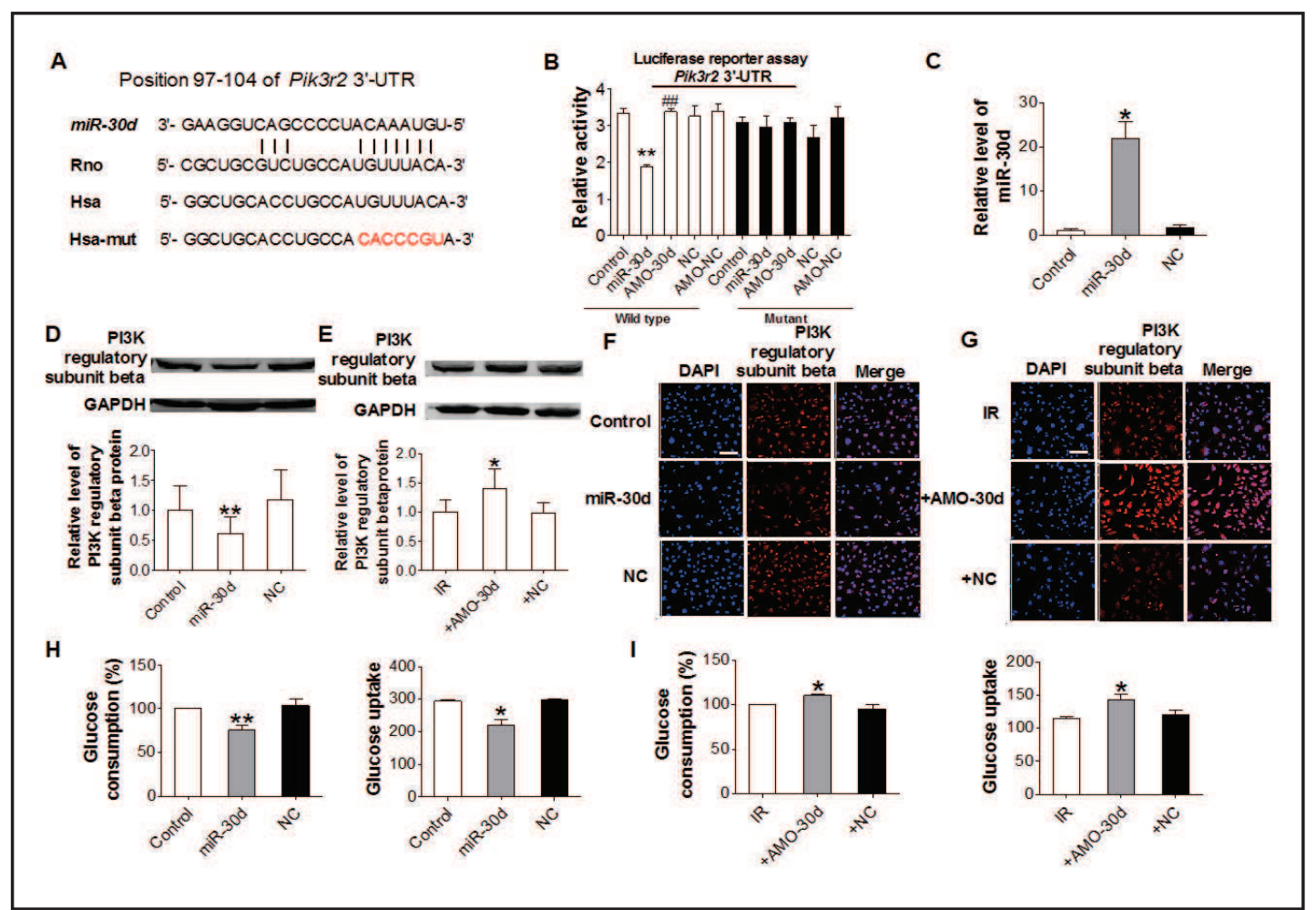

Fig. 4. MiR-30d targets PI3K regulatory subunit beta to regulate glucose metabolism in skeletal muscle cells. (A) Sequence alignment showing the nucleotide complementarity between miR-30d and the $3^{\prime}$-UTR of the rat Pik3r2 gene. The location of the nucleotide replacement mutation made to the seed site in $3^{\prime}$-UTR of $P i k 3 r 2$ is indicated in red. (B) Luciferase reporter gene assay showing the direct functional interactions between miR-30d and the 3'-UTR of Pik3r2, as revealed by the significantly reduced luciferase activities by miR-30d mimic. Note that AMO-30d, the antisense inhibitor of miR-30d, abolished the repressive effects and the mutated construct failed to affect luciferase activities. AMO-NC stands for negative control for AMO-30d. ${ }^{* *} \mathrm{p}<0.01$ compared with control; ${ }^{\# \#} \mathrm{p}<0.01$ compared with miR-27a; $\mathrm{n}=3$. (C) Verification of transfection efficiency of miR-30d mimic in L6 cells, determined by real-time RT-PCR (qPCR) (normalized to U6 as an internal control). ${ }^{* *} \mathrm{p}<0.01$ versus control; $\mathrm{n}=3$. (D) Down-regulation of PI3K regulatory subunit beta protein expression levels by miR-30d mimic in L6 cells. ${ }^{* *} \mathrm{p}<0.01$ vs. control; $\mathrm{n}=3$. (E) Upregulation of PI3K regulatory subunit beta protein levels by AMO-30d to knockdown endogenous miR-30d in insulin-resistant L6 cells (IR). * $\mathrm{p}<0.05$ vs. IR; $\mathrm{n}=3$. (F) Immunofluorescence staining showing the repressive effects of miR$30 \mathrm{~d}$ on PI3K regulatory subunit beta protein expression (red) in L6 cells. Cell nuclei were visualized by DAPI (blue). Scale bar $=100 \mu \mathrm{m}$. (G) Immunofluorescence staining showing the repressive effects of miR-30d on PI3K regulatory subunit beta protein expression (red) in insulin-resistant L6 cells. Cell nuclei were visualized by DAPI (blue). Scale bar $=100 \mu \mathrm{m}$. (H) Inhibition of glucose consumption (left panel) and glucose uptake (right panel) by miR-30d mimic in L6 cells. The level of basal glucose uptake was set to $100 \%{ }^{*} \mathrm{p}<$ $0.05,{ }^{* *} \mathrm{p}<0.01$ compared with control; $\mathrm{n}=3-5$. (I) Enhancement of glucose consumption (left panel) and glucose uptake (right panel) by AMO-30d to knockdown miR-30d in insulin-resistant L6 cells (IR). *p $<0.05$, compared with control; $\mathrm{n}=3$.

endogenous miR-106b, miR-27a and miR-30d all at once. As shown in Fig. 5A, the levels of miR-27a, miR-30d and miR-106b were reduced by $99.7 \%$, 99.1\%, and $58.7 \%$, respectively, upon transfection of the $\mathrm{MTg}-\mathrm{AMO}_{106 \mathrm{~b} / 27 \mathrm{a} / 30 \mathrm{~d}}$. We then went on to investigate the ability of the $\mathrm{MTg}^{-\mathrm{AMO}_{106 \mathrm{~b} / 27 \mathrm{a} / 30 \mathrm{~d}}}$ to relieve the tonic repressive effects of the three miRNAs on their respective target genes. As depicted Fig. $5 \mathrm{~B} \& \mathrm{C}, \mathrm{MTg}^{-} \mathrm{AMO}_{106 \mathrm{~b} / 27 / 30 \mathrm{~d}}$ markedly increased the expression of MAPK 14, PI3K regulatory subunit beta and GLUT4 at both the mRNA and 


\section{Cellular Physiology Cell Physiol Biochem 2016;38:2063-2078 \begin{tabular}{c|c|c|c|c|c|}
\hline DOI: 10.1159/000445565 & () 2016 The Author(s). Published by S. Karger AG, Basel
\end{tabular}

A

A

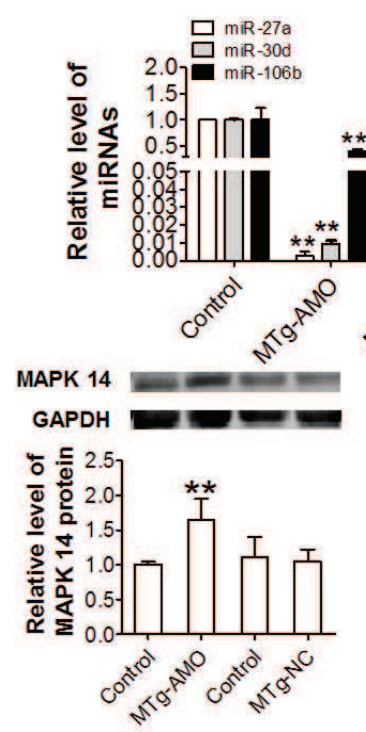

C

D DAPI MAPK 14 Merge

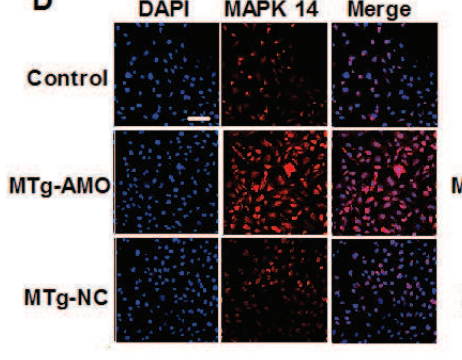

B

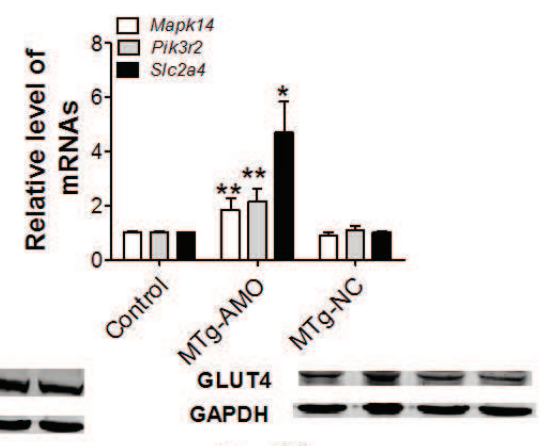

subunit beta
suPda
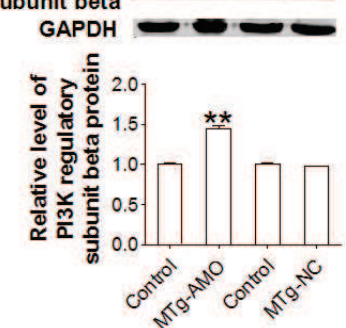

PI3K regulatory

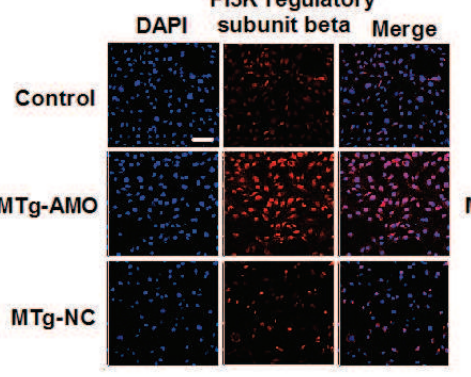

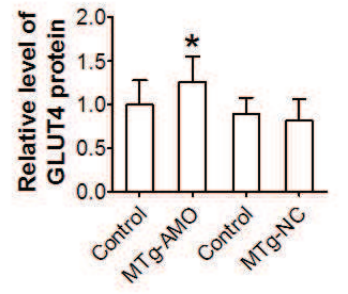

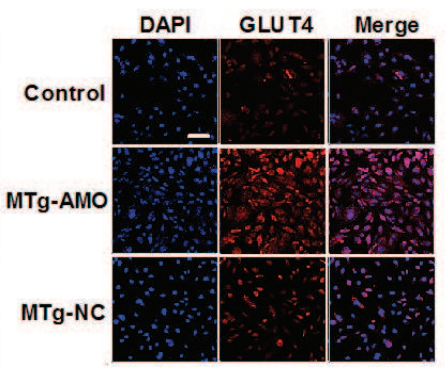

Fig. 5. Efficacies of MTg-AMO ${ }_{106 \mathrm{~b} / 27 \mathrm{a} / 30 \mathrm{~d}}$ in regulating miR-27a, miR-30d and miR-106b expression and their respective target genes in L6 cells. (A) Down-regulation of miR-27a, miR-30d and miR-106b expression by ${\mathrm{MTg}-\mathrm{AMO}_{106 \mathrm{~b} / 27 \mathrm{a} / 30 \mathrm{~d}}}$ MTg-AMO). ${ }^{* *} \mathrm{p}<0.01$ vs. Control; $\mathrm{n}=3$. (B) Upregulation of MAPK 14, PI3K regulatory subunit beta and GLUT4 transcript levels by MTg-AMO. ${ }^{*} \mathrm{p}<0.05$, ${ }^{* *} \mathrm{p}<0.01$ vs. Control; $\mathrm{n}=3-5$. (C) Increases of MAPK 14, PI3K regulatory subunit beta and GLUT4 protein levels by MTg-AMO. * $\mathrm{p}<0.05,{ }^{* *}$ $\mathrm{p}<0.01$ vs. Control; $n=3$. (D) Verification of upregulation of the cellular protein levels of MAPK 14, PI3K regulatory subunit beta and GLUT4 (red) by immunofluorescence staining assay in L6 cells. Cell nuclei were visualized using DAPI (blue). Scale bar $=100 \mu \mathrm{m}$.

protein levels. As expected, the MTg-NC did not alter the levels of these genes (Fig. 5B \& C). These results were further supported by our fluorescent staining assay (Fig. 5D).

$M T g-A M O_{106 b / 27 a / 30 d}$ improves glucose metabolism in L6 cells

The ability of MTg-AMO ${ }_{106 \mathrm{~b} / 27 \mathrm{a} / 30 \mathrm{~d}}$ to up-regulate the expression of GLUT4 predicts its ability to regulate glucose metabolism. This was indeed evidenced by the data shown in Fig. $6 \mathrm{~A} \& \mathrm{~B}$, the glucose consumption level and glucose uptake in L6 cells were both improved by MTg-AMO ${ }_{106 \mathrm{~b} / 27 \mathrm{a} / 30 \mathrm{~d}}$ treatment. In addition, MTg-AMO ${ }_{106 \mathrm{~b} / 27 \mathrm{a} / 30 \mathrm{~d}}$ increased GLUT4 fluorescence intensity and GLUT4 translocation from the cytoplasmic membrane to the cytoplasm as detected by our immunofluorescence analysis (Fig. 6C).

$M T g-A M O_{106 b / 27 a / 30 d}$ up-regulates GLUT4, MAPK 14 and PI3K regulatory subunit beta expression in insulin-treated $L 6$ cells

We then examined the effects of MTg-AMO ${ }_{106 \mathrm{~b} / 27 \mathrm{a} / 30 \mathrm{~d}}$ on GLUT4, MAPK 14 and PI3K regulatory subunit beta expression in insulin-treated L6 cells. As depicted in Fig. 7A, 


\section{Cellular Physiology Cell Physiol Biochem 2016;38:2063-2078

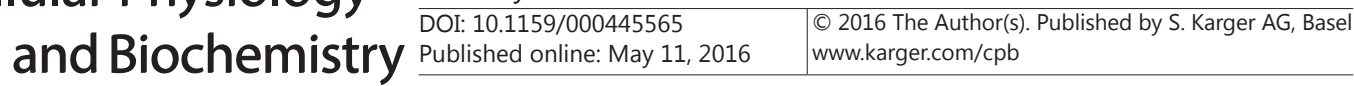 Zhou et al.: Multiple miRNAs Regulate Insulin Resistance}

Fig. 6. Effects of MTg-AMO on glucose metabolism in L6 cells. (A \& B) Increases in glucose consumption and glucose uptake by MTg-AMO. The degree of basal glucose consumption and glucose uptake in L6 cells was normalized to control. Note the absence of effects with MTg-NC as a negative control. $* \mathrm{p}<0.05,{ }^{* *} \mathrm{p}<0.01$ compared with control; $n=3-5$. (C) MTg-AMO induces translocation of GLUT4 (green) from the cytoplasmic membrane to the cytoplasm, as revealed by immunofluorescence microscopy. Cell nuclei were visualized by DAPI (blue). Scale bar = $100 \mu \mathrm{m}$.

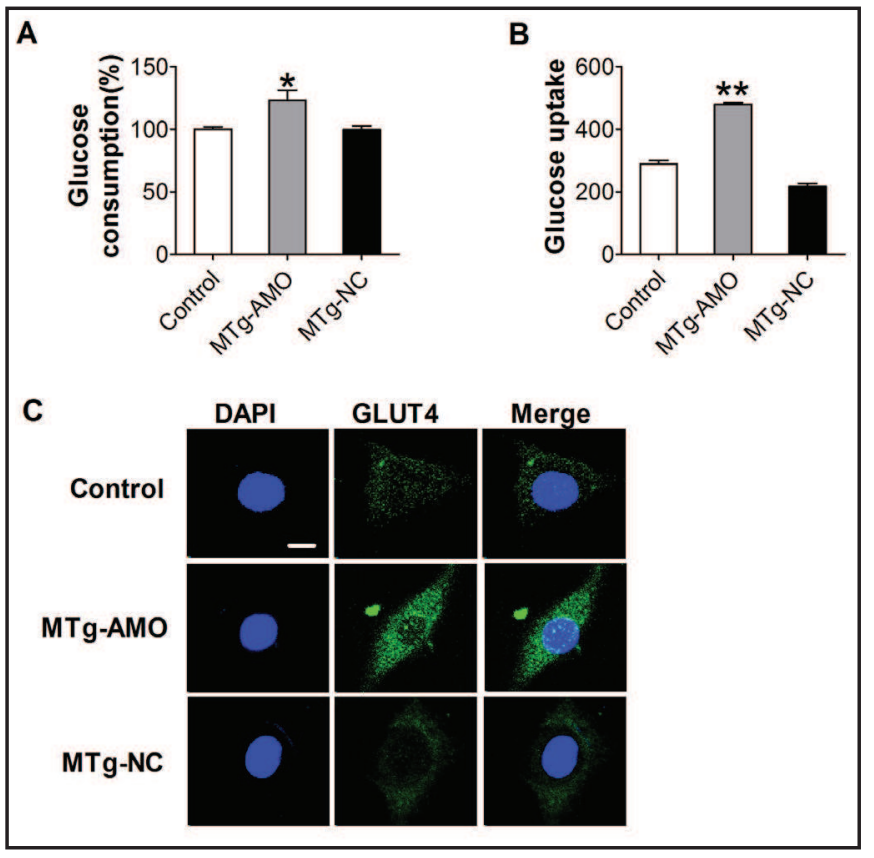

$\mathrm{MTg}-\mathrm{AMO}_{10 \mathrm{~b} / 27 \mathrm{a} / 30 \mathrm{~d}}$ markedly decreased the levels of miR-27a, miR-30d and miR-106b in insulin-treated L6 cells. In addition, the protein and mRNA levels of MAPK 14, PI3K regulatory subunit beta and GLUT4, the respective target genes of the three miRNAs, were conversely increased by MTg-AMO 106b/27a/30d (Fig. 7B \& C). Similar results were obtained by immunofluorescence staining (Fig. 7D).

Effects of MTg-AMO ${ }_{106 b / 27 a / 30 d}$ on glucose metabolism in insulin-treated L6 cells

As shown in Fig. 8A \& B, the glucose consumption level and glucose uptake were both markedly elevated by treatment with $\mathrm{MTg}^{-A M O_{106 / 27 a / 30 d}}$ in insulin-treated L6 cells. In addition, MTg-AMO ${ }_{106 \mathrm{~b} / 27 \mathrm{a} / 30 \mathrm{~d}}$ decreased GLUT4 expression and GLUT4 translocation (Fig. 8C).

\section{Discussion}

In the present study, we aimed to identify the miRNA regulators of the GLUT4 signalling pathway and their roles in governing glucose metabolism, and to assess the effectiveness of the MTg-AMO technique as a miRNA interference strategy for confirming the cellular and pathophysiological functions of miRNAs. Our experiments provided the following main findings. First, miR-106b, miR-27a and miR-30d were up-regulated in a rat model of T2DM and in insulin-resistant L6 cells. Second, the upregulation of these miRNAs diminished GLUT4 signalling by repressing the expression of GLUT4, MAPK 14 and PI3K regulatory subunit beta, respectively. Third, the impairment of the GLUT4 signalling pathway due, at least partially, to the upregulation of miR-106b, miR-27a and miR-30d resulted in considerable weakening of the glucose metabolism. Finally, normalization of endogenous levels of these three miRNAs by their respective antisense inhibitor AMOs effectively corrected the impaired GLUT4 signal transduction and restored the damaged glucose metabolism to normal levels. Notably, the MTg-AMO yielded significantly greater effects compared to the regular AMOs. These findings allow us to conclude: (1) miR-106b, miR-27a and miR-30d critically regulate the main components (GLUT4, MAPK 14 and PI3K regulatory subunit beta) of the GLUT4 signalling pathway; (2) deregulation of these miRNAs contributes significantly to glucose metabolism disorder thereby insulin resistance; and (3) the MTg-AMO approach is a superior strategy for concomitant normalization of deregulated miRNAs and subsequent glucose metabolism. 


\section{Cellular Physiology Cell Physiol Biochem 2016;38:2063-2078 \begin{tabular}{ll|l} 
aOI: 10.1159/000445565 & $\begin{array}{l}\text { @ 2016 The Author(s). Published by S. Karger AG, Basel } \\
\text { www.karger.com/cpb }\end{array}$ \\
\hline
\end{tabular}

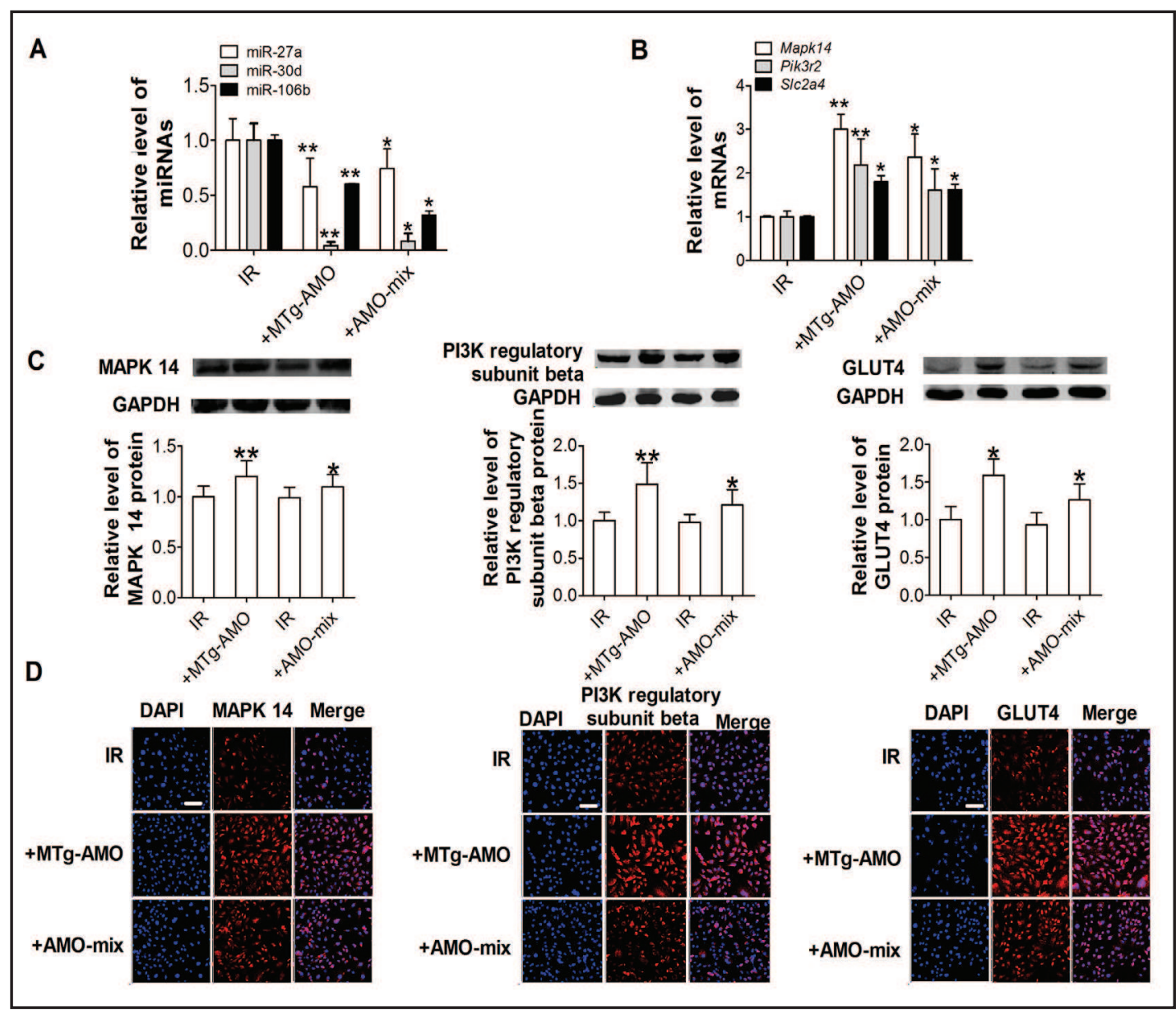

Fig. 7. Efficacies of MTg-AMO ${ }_{106 \mathrm{~b} / 27 \mathrm{a} / 30 \mathrm{~d}}$ in regulating miR-27a, miR-30d and miR-106b expression and their respective target genes in insulin-resistant L6 cells. (A) Down-regulation of miR-27a, miR-30d and miR106b expression by MTg-AMO ${ }_{106 \mathrm{~b} / 27 \mathrm{a} / 30 \mathrm{~d}}$ (MTg-AMO) and AMO-mix (a mixture of AMO-27a, AMO-30d and AM0-106b). * $\mathrm{p}<0.05$, ** $\mathrm{p}<0.01$ vs. IR; $\mathrm{n}=3$. (B) Upregulation of Mapk14, Pik3r2 and Slc2a4 mRNA levels by MTg-AMO and AMO-mix. * $\mathrm{p}<0.05$, ** $\mathrm{p}<0.01$ vs. IR; $\mathrm{n}=3$. (C) Increases of MAPK 14, PI3K regulatory subunit beta and GLUT4 protein levels by MTg-AMO and AMO-mix. ${ }^{*} \mathrm{p}<0.05,{ }^{* *} \mathrm{p}<0.01$ vs. IR; $\mathrm{n}=6$. (D) Verification of upregulation of the cellular protein levels of MAPK 14, PI3K regulatory subunit beta and GLUT4 (red) by immunofluorescence staining assay in L6 cells. Cell nuclei were visualized using DAPI (blue). Scale bar $=100 \mu \mathrm{m}$. IR, Insulin resistance.

Insulin resistance is an independent causal factor for diabetes mellitus[3, 9]. Defect in glucose uptake into skeletal muscles is a major reflection of insulin resistance and can be caused by impairment of a wide spectrum of cellular processes including glucose delivery, transport, and phosphorylation $[26,36]$. Yet, the precise mechanisms for insulin resistance are complex and remain incompletely understood [37, 38]. Among the various factors, GLUT4 is known to mediate the peripheral tissue insulin stimulation of glucose uptake in many tissues, particularly in skeletal muscle, because they help control glucose metabolism in muscular tissues [5, 39, 40]. Recent reports demonstrated that MAPK 14 is highly expressed and activated in human omental (OM) adipose tissue in obesity [41] and in liver $[42,43]$. Activation of MAPK 14 in liver is critically involved in the ROS-induced impairment of insulin signalling and in stress-induced IRS-1 serine phosphorylation as well, promoting hepatic insulin resistance [39]. MAPK 14 has been shown to increase GLUT4 expression and lipid accumulation in differentiated 3T3-L1 adipocytes [44]. Class IA phosphatidylinositol 


\section{Cellular Physiology \\ Cell Physiol Biochem 2016;38:2063-2078 and Biochemistry Published online: May 11, $2016 \quad \begin{aligned} & \text { O 2016 he Author(s) } \\ & \text { www.karger.com/cpb }\end{aligned}$ \\ Zhou et al.: Multiple miRNAs Regulate Insulin Resistance}

Fig. 8. Effects of MTg$\mathrm{AMO}_{106 \mathrm{~b} / 27 \mathrm{a} / 30 \mathrm{~d}}$ on glucose metabolism in insulin-resistant L6 cells. (A \& B) Increases in glucose consumption and glucose uptake by $\mathrm{MTg}^{-\mathrm{AMO}_{106 \mathrm{~b} / 27 \mathrm{a} / 30 \mathrm{~d}^{*}}}$ The degree of basal glucose consumption and glucose uptake in L6 cells was normalized to control. Mix represents the mixture of equal molar concentrations of AMO-106b, AMO27a, and AMO-30d. * p $<0.05$ compared with control; $\mathrm{n}=3-5$. (C) MTg-AMO ${ }_{106 \mathrm{~b} / 27 \mathrm{a} / 30 \mathrm{~d}}$ induces translocation of GLUT4 (green) from cytoplasmic membrane to cytoplasm, as revealed by immunofluorescence microscopy. Cell nuclei were visualized by DAPI (blue). Scale bar $=100 \mu \mathrm{m}$. IR, Insulin resistance.
A

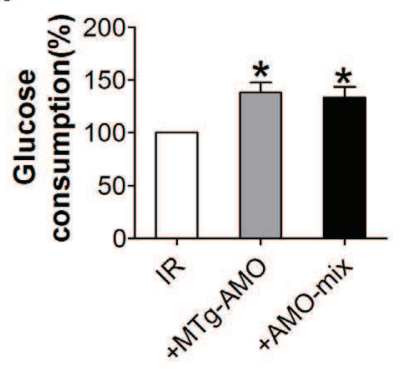

C

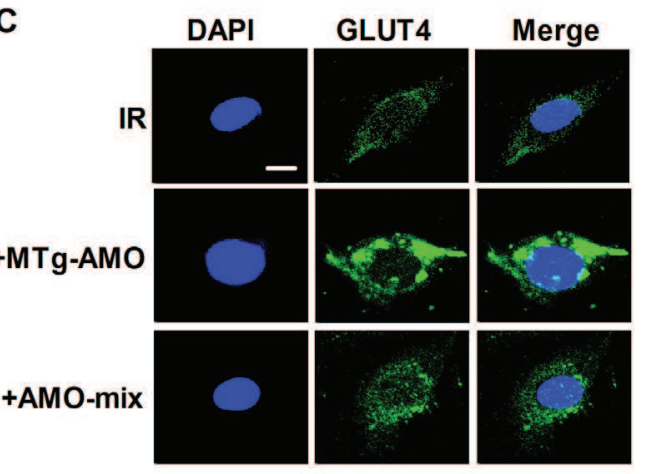

B

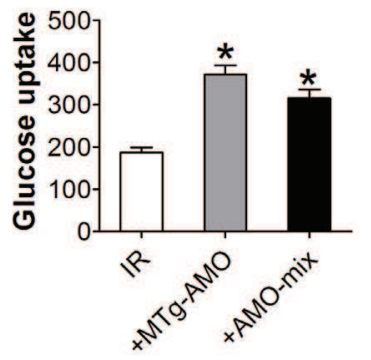

+MTg-AMO

3-kinase (PI3K) plays an important role in regulating metabolism and $\beta$-cell function [45, 46].

While these aforementioned studies support the critical involvement of GLUT4, MAPK 14 and PI3K regulatory subunit beta in regulating glucose metabolism with their expression deregulation and functional impairment favouring insulin resistance, these genes are under the delicate regulation by miRNAs. For instance, overexpression of let-7 can result in insulin resistance and impaired glucose tolerance [38, 47]; in contrast, knockdown of the let-7 family miRNAs reverses impaired glucose tolerance, presumably by improving insulin sensitivity in the liver and muscles $[39,48]$. Previous studies showed that in insulin-responsive tissues such as skeletal muscles, PI3K can induce phosphorylation of Akt that directly mediates GLUT4 trafficking to the plasma membrane [49]. Insulin results in p38-induced GLUT4 activation in muscles and fat cells, and MAPK 14 can induce GLUT4 activation at the plasma membrane even in the absence of insulin treatment [50]. Our bioinformatics analysis and in vitro study revealed that miR-27a, miR-106b and miR-30d could regulate MAPK 14, GLUT4 and PI3K regulatory subunit beta, respectively, in L6 cells, which suggests that all three miRNAs contribute to the cellular functions relevant to the insulin signaling pathway in rat. In addition, miR-30d was significantly elevated in newly diagnosed T2DM patients compared with individuals with normal glucose tolerance [33]. MiR-106b is associated with skeletal muscle insulin resistance and T2DM [34]. The expression of miR-27a was found increase in adipose tissue of a spontaneous T2DM rat model [35]. MAPK 14 or PI3K regulatory subunit beta locates upstream of GLUT4 in the signaling pathway; this conclusion stems from both published studies and the results generated in the present study. Previous studies have shown that in insulin-responsive tissues such as skeletal muscle, PI3K can induce phosphorylation of Akt that directly mediates GLUT4 trafficking to the plasma membrane. MAPK 14 activation by insulin regulates GLUT4 activity [33], and MAPK 14 -mediated activation of GLUT4 occurs at the plasma membrane. These results suggest that both of the PI3K-Akt MAPK 14 signaling pathways influence GLUT4 translocation and activation, and expression. In our study, we found that miR-27a, miR-106b and miR-30d regulated MAPK 14, GLUT4 and PI3K regulatory subunit beta, respectively, in L6 cells, suggesting that all three miRNAs contribute to GLUT4 signaling. 


\section{Cellular Physiology Cell Physiol Biochem 2016;38:2063-2078 \begin{tabular}{ll|l}
${ } }$ & $\begin{array}{l}\text { () 2016 The Author(s). Published by S. Karger AG, Basel } \\
\text { www.karger.com/cpb }\end{array}$ \\
\hline
\end{tabular} \\ Zhou et al.: Multiple miRNAs Regulate Insulin Resistance}

Here, we found that miR-106b/27a/30d expression was increased in diabetic skeletal muscle and GLUT4/MAPK 14/PI3K regulatory subunit beta as the target genes of these three miRNAs were reciprocally down-regulated. The down-regulation of GLUT4/MAPK 14/PI3K regulatory subunit beta eventually resulted in glucose metabolism disorders. These adverse changes were reversible: normalization or knockdown of miR-106b/27a/30d levels by their specific antisense inhibitors (AMOs) abrogated the metabolic disturbances.

Our findings further support the view that the GLUT4/MAPK14/PI3K regulatory subunit beta pathway in connection to the glucose metabolism is regulated by multiple miRNAs. In order to maintain the normal functions of these proteins, concurrent modification of the related miRNAs is highly desirable. In respect with this notion, we examined the effects of multiple-target AMO strategy that allows for concurrent inhibition of pre-determined multiple miRNAs by a single AMO fragment. The theory of MTg-AMO has been examined in a previous study [28]; miR-21, miR-155 and miR-17 promote tumour genesis and the antisense inhibitors of these three miRNAs are integrated into a single fragment. The result showed that the effect of MTg-AMO ${ }_{21 / 155 / 17-5 \mathrm{p}}$ is stronger than the combined use of the same dose of a single miRNA antisense nucleotide (AMO-21, AMO-155 and AMO-17). In this study, we tested the effect of MTg-AMO ${ }_{106 b / 27 a / 30 d}$ on glucose metabolism using the MTg-AMO approach, and found that MTg-AMO ${ }_{106 \mathrm{~b} / 2 \mathrm{a} / 30 \mathrm{~d}}$ offered superior efficacy over a single regular AMOs. However, more rigorous studies are warranted to optimize the desired effectiveness of MTg-AMO $106 \mathrm{~b} / 27 \mathrm{a} / 30 \mathrm{~d}^{*}$

\section{Acknowledgements}

This work was supported in part by the National Nature Science Foundation of China (81200593, 81570399, 81270042), and the Program for New Century Excellent Talents in Heilongjiang Provincial University (1254-NCET-01). The funders have no role in study design, data collection and analysis, decision to publish, or preparation of the manuscript.

\section{Disclosure Statement}

The authors declare that no competing interest exists.

\section{References}

1 Chiasson JL, Josse RG, Gomis R, Hanefeld M, Karasik A, Laakso M: STOP-NIDDM Trail Research Group: Acarbose for prevention of type 2 diabetes mellitus: the STOP-NIDDM randomised trial. Lancet 2002;359:2072-2077.

2 Navas-Acien A, Silbergeld EK, Streeter RA, Clark JM, Burke TA, Guallar E: Arsenic exposure and type 2 diabetes: a systematic review of the experimental and epidemiological evidence. Environ Health Perspect 2006;114:641-648.

3 Ginter E, Simko V: Diabetes type 2 pandemic in 21st century. Bratisl Lek Listy 2010;111:134-137.

4 Sung KC, Jeong WS, Wild SH, Byrne CD: Combined influence of insulin resistance, overweight/obesity, and fatty liver as risk factors for type 2 diabetes. Diabetes Care 2012;35:717-722.

5 Tsai S, Clemente-Casares X, Revelo XS, Winer S, Winer DA: Are obesity-related insulin resistance and type 2 diabetes autoimmune diseases? Diabetes 2015;64:1886-1897.

6 Poletto AC, David-Silva A, Yamamoto AP, Machado UF, Furuya DT: Reduced Slc2a4/GLUT4 expression in subcutaneous adipose tissue of monosodium glutamate obese mice is recovered after atorvastatin treatment. Diabetol Metab Syndr 2015;7:18.

7 Fang P, Shi M, Guo L, He B, Wang Q Yu M, Bo P, Zhang Z: Effect of endogenous galanin on glucose transporter 4 expression in cardiac muscle of type 2 diabetic rats. Peptides 2014;62:159-163. 


\section{Cellular Physiology Cell Physiol Biochem 2016;38:2063-2078 \begin{tabular}{ll|l}
${ } }$ & $\begin{array}{l}\text { @ 2016 The Author(s). Published by S. Karger AG, Basel } \\
\text { www.karger.com/cpb }\end{array}$ \\
\hline
\end{tabular}}

Zhou et al.: Multiple miRNAs Regulate Insulin Resistance

8 Castorena CM, Arias EB, Sharma N, Bogan JS, Cartee GD: Fiber type effects on contraction-stimulated glucose uptake and GLUT4 abundance in single fibers from rat skeletal muscle. Am J Physiol Endocrinol Metab 2015;308:E223-230.

9 Baranowski M, Zabielski P, Błachnio-Zabielska AU, Harasim E, Chabowski A,Górski J: Insulin-sensitizing effect of LXR agonist T0901317 in high-fat fed rats is associated with restored muscle GLUT4 expression and insulin-stimulated AS160 phosphorylation. Cell Physiol Biochem 2014;33:1047-1057.

10 Yoshino H, Seki N, Itesako T, Chiyomaru T, Nakagawa M, Enokida H:Aberrant expression of microRNAs in bladder cancer. Nat Rev Urol 2013;10:396-404.

11 Yang GH, Wang F, Yu J, Wang XS, Yuan JY, Zhang JW: MicroRNAs are involved in erythroid differentiation control. J Cell Biochem 2009;107:548-556.

12 Zhang Z, Chang H, Li Y, Zhang T, Zou J, Zheng X, Wu J: MicroRNAs: potential regulators involved in human anencephaly. Int J Biochem Cell Biol 2010;42:367-374.

13 Gauthier BR, Wollheim CB: MicroRNAs: 'ribo-regulators' of glucose homeostasis. Nat Med 2006;12:36-38.

14 Hammond SM. MicroRNA therapeutics: a new niche for antisense nucleic acids. Trends Mol Med 2006;12:99-101.

15 Yang B, Lin H, Xiao J, Lu Y, Luo X, Li B, Zhang Y, Xu C, Bai Y, Wang H, Chen G, Wang Z: The muscle-specific microRNA miR-1 regulates cardiac arrhythmogenic potential by targeting GJA1 and KCNJ2. Nat Med 2007;13:486-491.

16 Wijesekara N, Zhang LH, Kang MH, Abraham T, Bhattacharjee A, Warnock GL, Verchere CB, Hayden MR: miR-33a modulates ABCA1 expression, cholesterol accumulation, and insulin secretion in pancreatic islets. Diabetes 2012;61:653-658.

17 Wang L, Zhang N, Pan HP, Wang Z, Cao ZY: MiR-499-5p Contributes to Hepatic Insulin Resistance by Suppressing PTEN. Cell Physiol Biochem 2015;36:2357-2365.

18 Baroukh N, Ravier MA, Loder MK, Hill EV, Bounacer A, Scharfmann R, Rutter GA, Van Obberghen E: MicroRNA-124a regulates Foxa2 expression and intracellular signaling in pancreatic beta-cell lines. J Biol Chem 2007;282:19575-19588.

19 Dou L, Wang S, Sui X, Meng X, Shen T, Huang X, Guo J, Fang W, Man Y, Xi J, Li J: MiR-301a mediates the effect of IL- 6 on the AKT/GSK pathway and hepatic glycogenesis by regulating PTEN expression. Cell Physiol Biochem 2015;35:1413-1424.

20 Chuang TY, Wu HL, Chen CC, Gamboa GM, Layman LC, Diamond MP, Azziz R, Chen YH: MicroRNA-223 Expression Is Upregulated in Insulin Resistant Human Adipose Tissue. J Diabetes Res 2015;2015:943659.

21 Poy MN, Spranger M, Stoffel M: microRNAs and the regulation of glucose and lipid metabolism. Diabetes Obes Metab 2007;9:67-73.

22 Xu P, Vernooy SY, Guo M, Hay BA: The Drosophila microRNA Mir-14 suppresses cell death and is required for normal fat metabolism. Curr Biol 2003;13:790-795.

23 Feng YY, Xu XQ Ji CB, Shi CM, Guo XR, Fu JF: Aberrant hepatic microRNA expression in nonalcoholic fatty liver disease. Cell Physiol Biochem 2014;34:1983-1997.

24 He A, Zhu L, Gupta N, Chang Y, Fang F: Overexpression of micro ribonucleic acid 29, highly up-regulated in diabetic rats, leads to insulin resistance in 3T3-L1 adipocytes. Mol Endocrinol 2007;21:2785-2794.

25 Chakraborty C, Doss CG, Bandyopadhyay S, Agoramoorthy G: Influence of miRNA in insulin signaling pathway and insulin resistance: micro-molecules with a major role in type-2 diabetes. Wiley Interdiscip Rev RNA 2014;5:697-712.

26 Horie T, Ono K, Nishi H, Iwanaga Y, Nagao K, Kinoshita M, Kuwabara Y, Takanabe R, Hasegawa K, Kita T, Kimura T: MicroRNA-133 regulates the expression of GLUT4 by targeting KLF15 and is involved in metabolic control in cardiac myocytes. Biochem Biophys Res Commun 2009;389:315-320.

27 Lu H, Buchan RJ, Cook SA: MicroRNA-223 regulates Glut4 expression and cardiomyocyte glucose metabolism. Cardiovasc Res 2010;86:410-420.

28 Lu Y, Xiao J, Lin H, Bai Y, Luo X, Wang Z, Yang B: A single anti-microRNA antisense oligodeoxyribonucleotide (AMO) targeting multiple microRNAs offers an improved approach for microRNA interference. Nucleic Acids Res 2009;37:e24.

29 Ai J, Wang N, Yang M, Du ZM, Zhang YC, Yang BF: Development of Wistar rat model of insulin resistance. World J Gastroenterol 2005;11:3675-3679.

30 Ai J, Yan X, Zhao L, Lu Y, Liang F, Cai B, Li G, Lu Y, Yang B: The protective effect of Daming capsule on heart function in streptozocin-induced diabetic rats with hyperlipidemia. Biol Pharm Bull 2009;32:1354-1358. 


\section{Cellular Physiology Cell Physiol Biochem 2016;38:2063-2078 \begin{tabular}{ll|l}
${ } }$ & $\begin{array}{l}\text { @ 2016 The Author(s). Published by S. Karger AG, Basel } \\
\text { www.karger.com/cpb }\end{array}$ \\
\hline
\end{tabular}}

Zhou et al.: Multiple miRNAs Regulate Insulin Resistance

31 Shen N, Li X, Zhou T, Bilal MU, Du N, Hu Y, Qin W, Xie Y, Wang H, Wu J, Ju J, Fang Z, Wang L, Zhang Y: Shensong Yangxin Capsule prevents diabetic myocardial fibrosis by inhibiting TGF-beta1/Smad signaling. J Ethnopharmacol 2014;157:161-170.

32 Kallen AN, Zhou XB, Xu J, Qiao C, Ma J, Yan L, Lu L, Liu C, Yi JS, Zhang H, Min W, Bennett AM, Gregory RI, Ding Y, Huang Y: The imprinted H19 lncRNA antagonizes let-7 microRNAs. Mol Cell 2013;52:101-112.

33 Kong L, Zhu J, Han W, Jiang X, Xu M, Zhao Y, Dong Q, Pang Z, Guan Q, Gao L, Zhao J, Zhao L: Significance of serum microRNAs in pre-diabetes and newly diagnosed type 2 diabetes: a clinical study. Acta Diabetol 2011;48:61-69.

34 Zhang Y, Yang L, Gao YF, Fan ZM, Cai XY, Liu MY, Guo XR, Gao CL, Xia ZK: MicroRNA-106b induces mitochondrial dysfunction and insulin resistance in C2C12 myotubes by targeting mitofusin-2. Mol Cell Endocrinol 2013;381:230-240.

35 Herrera BM, Lockstone HE, Taylor JM, Ria M, Barrett A, Collins S, Kaisaki P, Argoud K, Fernandez C, Travers ME, Grew JP, Randall JC, Gloyn AL, Gauguier D, McCarthy MI, Lindgren CM: Global microRNA expression profiles in insulin target tissues in a spontaneous rat model of type 2 diabetes. Diabetologia 2010;53:10991109.

36 Cline GW, Petersen KF, Krssak M, Shen J, Hundal RS, Trajanoski Z, Inzucchi S, Dresner A, Rothman DL, Shulman GI: Impaired glucose transport as a cause of decreased insulin-stimulated muscle glycogen synthesis in type 2 diabetes. N Engl J Med 1999;341:240-246.

37 Rezende LF1, Santos GJ, Santos-Silva JC, Carneiro EM, Boschero AC: Ciliary neurotrophic factor (CNTF) protects non-obese Swiss mice against type 2 diabetes by increasing beta cell mass and reducing insulin clearance. Diabetologia 2012;55:1495-1504.

38 Sato K, Nakamura A, Shirakawa J, Muraoka T, Togashi Y, Shinoda K, Orime K, Kubota N, Kadowaki T, Terauchi Y: Impact of the dipeptidyl peptidase-4 inhibitor vildagliptin on glucose tolerance and $\beta$-cell function and mass in insulin receptor substrate-2-knockout mice fed a high-fat diet. Endocrinology 2012;153:1093-1102.

39 Lizunov VA, Stenkula KG, Lisinski I, Gavrilova O, Yver DR, Chadt A, Al-Hasani H, Zimmerberg J, Cushman SW: Insulin stimulates fusion, but not tethering, of GLUT4 vesicles in skeletal muscle of HA-GLUT4-GFP transgenic mice. Am J Physiol Endocrinol Metab 2012;302:E950-960.

40 Baron AD1, Brechtel G, Wallace P, Edelman SV: Rates and tissue sites of non-insulin- and insulin-mediated glucose uptake in humans. Am J Physiol 1988;255:E769-774.

41 Blüher M, Bashan N, Shai I, Harman-Boehm I, Tarnovscki T, Avinaoch E, Stumvoll M, Dietrich A, Klöting N, Rudich A: Activated Ask1-MKK4-p38MAPK/JNK stress signaling pathway in human omental fat tissue may link macrophage infiltration to whole-body Insulin sensitivity. J Clin Endocrinol Metab 2009;94:2507-2515.

42 Al-Lahham R, Deford JH, Papaconstantinou J: Mitochondrial-Generated ROS Down Regulates Insulin Signaling via Activation of the p38MAPK Stress Response Pathway. Mol Cell Endocrinol 2016;419:1-11.

43 Hemi R, Yochananov Y, Barhod E, Kasher-Meron M, Karasik A, Tirosh A, Kanety H: p38 mitogen-activated protein kinase-dependent transactivation of ErbB receptor family: a novel common mechanism for stressinduced IRS-1 serine phosphorylation and insulin resistance. Diabetes 2011;60:1134-1145.

44 Shen Y, Zhao Y, Zheng D , Chang X, Ju S, Guo L: Effects of orexin A on GLUT4 expression and lipid content via MAPK signaling in 3T3-L1 adipocytes. J Steroid Biochem Mol Biol 2013;138:376-383.

45 Engelman JA, Luo J, Cantley LC: The evolution of phosphatidylinositol 3-kinases as regulators of growth and metabolism. Nat Rev Genet 2006;7:606-619.

46 Manna P, Jain SK: Phosphatidylinositol-3,4,5-triphosphate and cellular signaling: implications for obesity and diabetes. Cell Physiol Biochem 2015;35:1253-1275.

47 Zhu H, Shyh-Chang N, Segrè AV, Shinoda G, Shah SP, Einhorn WS, Takeuchi A, Engreitz JM, Hagan JP, Kharas MG, Urbach A, Thornton JE, Triboulet R, Gregory RI; DIAGRAM Consortium; MAGIC Investigators, Altshuler D, Daley GQ: The Lin28/let-7 axis regulates glucose metabolism. Cell 2011;147:81-94.

48 Frost RJ, Olson EN: Control of glucose homeostasis and insulin sensitivity by the Let-7 family of microRNAs. Proc Natl Acad Sci USA 2011;108:21075-21080.

49 Michelle Furtado L, Poon V, Klip A: GLUT4 activation: thoughts on possible mechanisms. Acta Physiol Scand 2003;178:287-296.

50 Ueda-Wakagi M, Mukai R, Fuse N, Mizushina Y, Ashida H: 3-O-Acyl-epicatechins Increase Glucose Uptake Activity and GLUT4 Translocation through Activation of PI3K Signaling in Skeletal Muscle Cells. Int J Mol Sci 2015;16:16288-16299. 